\title{
Ground Water Arsenic Pollution in West Bengal and Bangladesh: Role of Quaternary Stratigraphy and Sedimetation
}

\author{
Acharyya SK* \\ Department of Geological Sciences, Jadavpur University, India \\ *Corresponding author: Acharyya SK, Department of Geological Sciences, Jadavpur University, Kolkata, India
}

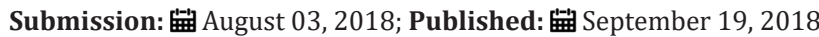

\begin{abstract}
Arsenic pollution is pervasive at shallow depth in low-land organic rich Holocene $(\sim 10,000$ year BP) alluvium in southern parts of the Bengal Delta. The upland terraces, mainly made up of Pleistocene $(\sim 10,000 \mathrm{yr}$ to $\sim 1.8 \mathrm{my}$ BP) sediments and capped by an oxidised zone, are free of arsenic problem [1,2]. Arsenic is sourced mainly from the Himalaya. Damodar fan delta, although entirely drained through Peninsular India, is also marginally affected. No arsenic mineral is present in contaminated alluvial aquifers; instead it occurs adsorbed on Hydrated Ferric Oxide (HFO), which generally coats sediment grains. Arsenic is released to groundwater mainly by bio-mediated reductive dissolution of HFO with corresponding oxidation of organic matter. Arsenic concentration in alluvium is broadly uniform, thus release process rather than source is important factor in arsenic pollution. Dug-well because of their oxygenated nature is useful low cost source of arsenic-safe water even in contaminated areas. This is particularly relevant in areas located away from surface water sources.
\end{abstract}

\section{Introduction}

Arsenic toxicity in groundwater affecting major parts of the Bengal Basin covering Bangladesh and southern West Bengal is a stupendous environmental problem $[3,4]$. Shallow tube-wells were sunk indiscriminately for lift irrigation. This resulted in over withdrawal, misuse and abuse of groundwater resource and also triggered release of arsenic to ground water. Ironically arsenic pollution in Bangladesh and West Bengal came to light after incurring huge investments. Groundwater irrigation for high yielding 'Boro' rice and a switch to multi-crop practices achieved 'Green Revolution'. It also reduced infant mortality from diarrheal diseases. Unexpectedly the practice also ushered arsenic malady in deltaic areas and parts of flood-plain domains of greater Bengal. The affected areas are virtually free of any industrial, mining or thermal-water activities and represent natural geological settings.

Role of Quaternary Sedimentation and Stratigraphy Causing Arsenic Toxicity in Bengal Delta

The Rivers Ganga, Brahmaputra and Meghna, fed by the tributaries from the Himalaya, Indoburma Range, and Peninsular India flow into the Bengal Delta spaning $\sim 1.4 \times 105 \mathrm{~km}^{2}$ in area covering most of Bangladesh and parts of West Bengal, India. The Bhagirathi River, one of the main distributory of the Ganga River, has scoured its recent and immediately older deltaic basins during the Quaternary sea level fluctuations [1]. Four geomorphic and morpho-stratigraphic units have been identified in West Bengal and bordering Bihar and Jharkhand States in India and in Assam bordering Bangladesh (Figure 1). The western uplands of undulating hills of older rocks framing the Bengal delta are divisible into three stepped alluvial plains: e.g., western belt of older rocks and the Laterite Plain, the Older Alluvial Plain (OAP) and the Younger Delta Plain (YDP) (Figure 2). Based on integrated analysis of these morpho-stratigraphic units and a few borehole records, subsurface extension of some of these units have been postulated to marginal parts of the Bengal Delta, whereas, several Holocene $(\sim 10,000$ yr BP) subsurface units extending beneath YDP are not exposed. Areas covering ODP and older surfaces are free of arsenic contamination, which affects parts of YDP spanning areas mainly to the east of the Bhagirathi River.

The presence of Youngest Toba-Ash Bed marker (75,000yr BP) has been recorded from the basal parts of the Quaternary profile located a little to the west of the Bengal Basin margin (Acharyya and Basu, 1993). These beds are tentatively correlated with the younger laterite topped Quaternary unit, which may be tentatively assigned Pleistocene-early Holocene age, whereas, the Older Alluvial Plain (OAP) deposits to its immediate east are early Holocene in age $[1,5]$. The sedimentation in the Bhagirathi-Ganga delta plain is strongly influenced by sea-level changes during the Late Pleistocene and Holocene time. The OAP deposits in West Bengal are truncated, incised and superposed by the lower level terraces of YDP, which in turn is incised by the present channel and floodplains of the river Bhagirathi (Figure 2). The tributaries responsible for the deposition of OAP in West Bengal had their courses at high angle to the present Bhagirathi course. The top sections of OAP sediments are oxidized, parts of these have been eroded and parts dip beneath the cover of YDP. 
The Holocene sediments beneath YDP in West Bengal and Bangladesh have been tentatively classified into three broad stratigraphic units (Figure 3) based on limited subsurface data $[1,6]$. These alluvial units are not layer cake in geometry. Thus at places late Pleistocene sediments can occur at shallow depth and incised Holocene channels may occupy deeper levels. The near surface Unit 3 consists of mud, silt, fine sand and locally present peat beds; Unit 2 is dominantly composed of fine, often dirty sand with clay intercalations; whereas, the Unit 1 is coarser, cleaner and sandy. Most arseniferous tube wells generally tap aquifers in Unit 2. C14 (radio carbon) ages from organic matter in the basal Unit 1 range from $\sim 28,300$ to $\sim 12,300 \mathrm{yr}$ BP. The basal sand and gravel bearing Unit 1 was deposited in entrenched paleochannels during Late Pleistocene and earliest Holocene under low-stand setting $[1,6]$. Sea-level gradually decreased and reached their lowest level of $\sim 135 \mathrm{~m}$ during the Late Pleistocene around 18,000yr BP, when the Pleistocene and Late Tertiary sediments located over the present Ganga delta and shelf areas were exposed to erosion and oxidation. Parts of Pleistocene alluvium covering the present delta region remained as incised upland terraces, which were dissected by the proto-Bhagirathi-Ganga-Brahmaputra river system. The Pleistocene terraces, capped by oxidized sediments and hard brown-bluish gray impervious clay paleosol formed interfluve uplands. These were dissected by Holocene sedimentfilled paleochannels and partly buried under younger deltaic Holocene sediments. The hard clayey aquitard corresponding to the Last Glacial Maximum Paleosol (LGMP) strongly influenced groundwater flow and controlled location of arsenic pollution to shallow aquifer in the Bengal Delta $[7,8]$. The basal sand and gravel unit was not uniformly developed but was mainly restricted to paleochannel floors (Figure $2 \& 3$ ).

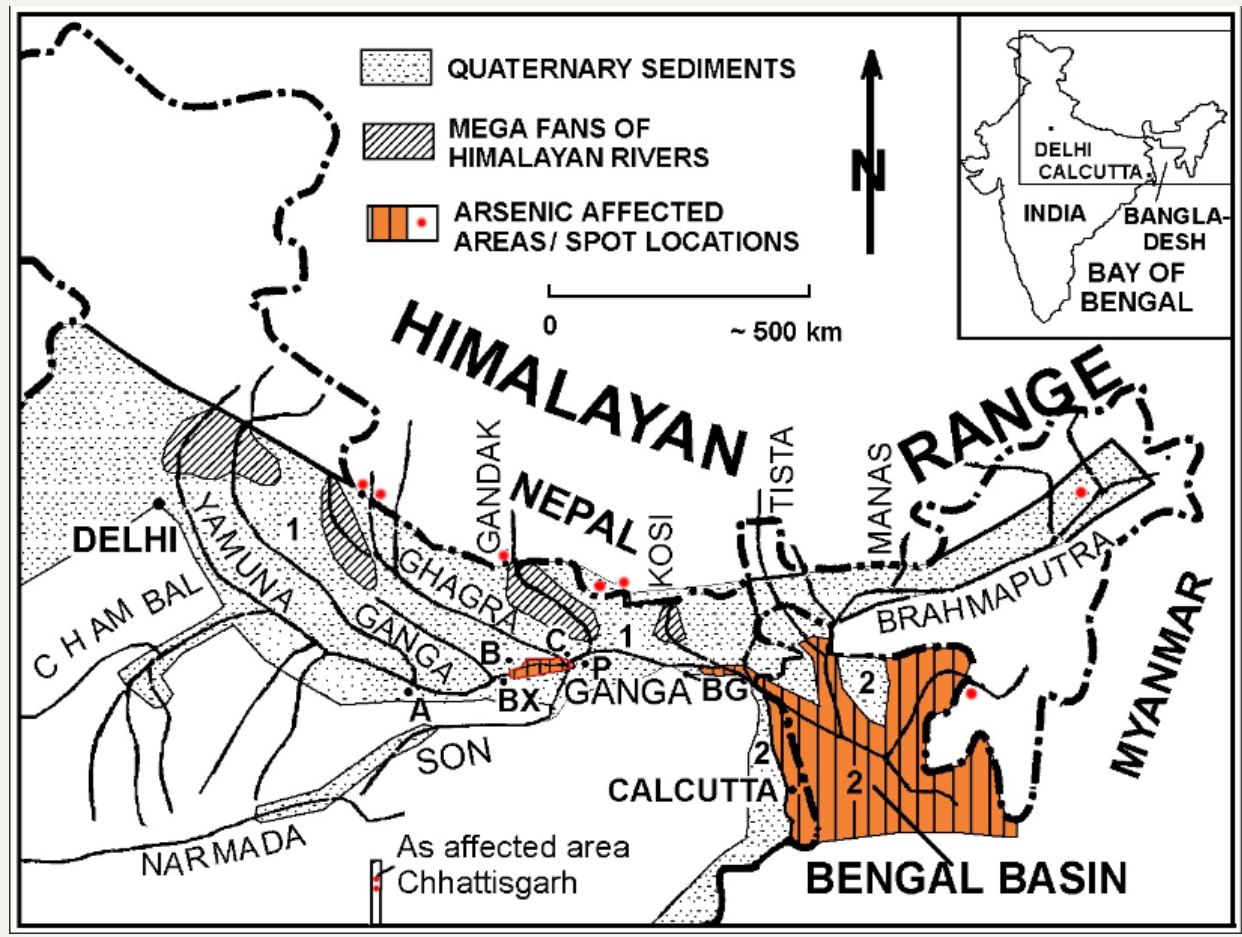

Figure 1: Arsenic contaminated areas in the Indian subcontinent.

1-Ganga-Brahmaputra alluvial plain; 2- Landforms and depositional environments in parts of Bangal Basin.

C: Abbreviated localities; A-Arah; B: Balia; C: Chhapra; G: Ghetugachhi; K: Kolkata, Rn: Raninagar

The rising sea level at the initial stages would have flooded the partly sediment covered entrenched valley courses of protoBhagirathi and the Ganga-Brahmaputra rivers, and converted their lower and adjacent parts to fluvial marshes, lagoons and estuaries. Swamps were formed ahead of the rising sea level. High tides in the Bay of Bengal advanced the tidal flat and mangrove growth to invade the delta mouth, which would clog with mud and silt rich in organic content. Thus, clay and silt enriched in organic matter and interbedded with lenticular sand bodies from numerous transient tributary channels dominated the middle unit.

Sea-level again began to rise rapidly between 7000 to $5500 \mathrm{yr}$ $\mathrm{BP}$, reaching higher than the present level and southern parts of the
Ganga-Bhagirathi delta were invaded further by tidal mangrove and encroached by the Bay of Bengal. These sediments occur at $7 \mathrm{~m}$ to $2 \mathrm{~m}$ beneath msl. There was widespread development of marine and fresh water peat layers around Kolkata and about $60 \mathrm{~km}$ further north during 7000 to $2000 \mathrm{yr}$ BP.

\section{Arsenic Toxicity in Parts of Damudar Fan-Delta}

The Damodar river was flowing east to meet the Bhagirathi River during the middle of 18th century, but it has since rotated its course over its fan shifting its mouth $128 \mathrm{~km}$ to the south. The Ajoy river located further north, still flows east to meet the Bhagirathi river, which was the regional slope also followed by the older 
proto-Damodar and other tributary rivers of the western upland. The Bhagirathi River system continued to remain to the east of the proto-Damodar and Damodar fan (Figure 2). Although arsenic affected areas are mainly located to the east of the Bhagirathi river, a few areas west of the Bhagirathi River are also arsenic affected (Figure 2) [7]. Many affected areas are located over the Damodar fan-delta, where maximum As concentrations of $85-90 \mu \mathrm{g} / \mathrm{L}$ have been recorded.

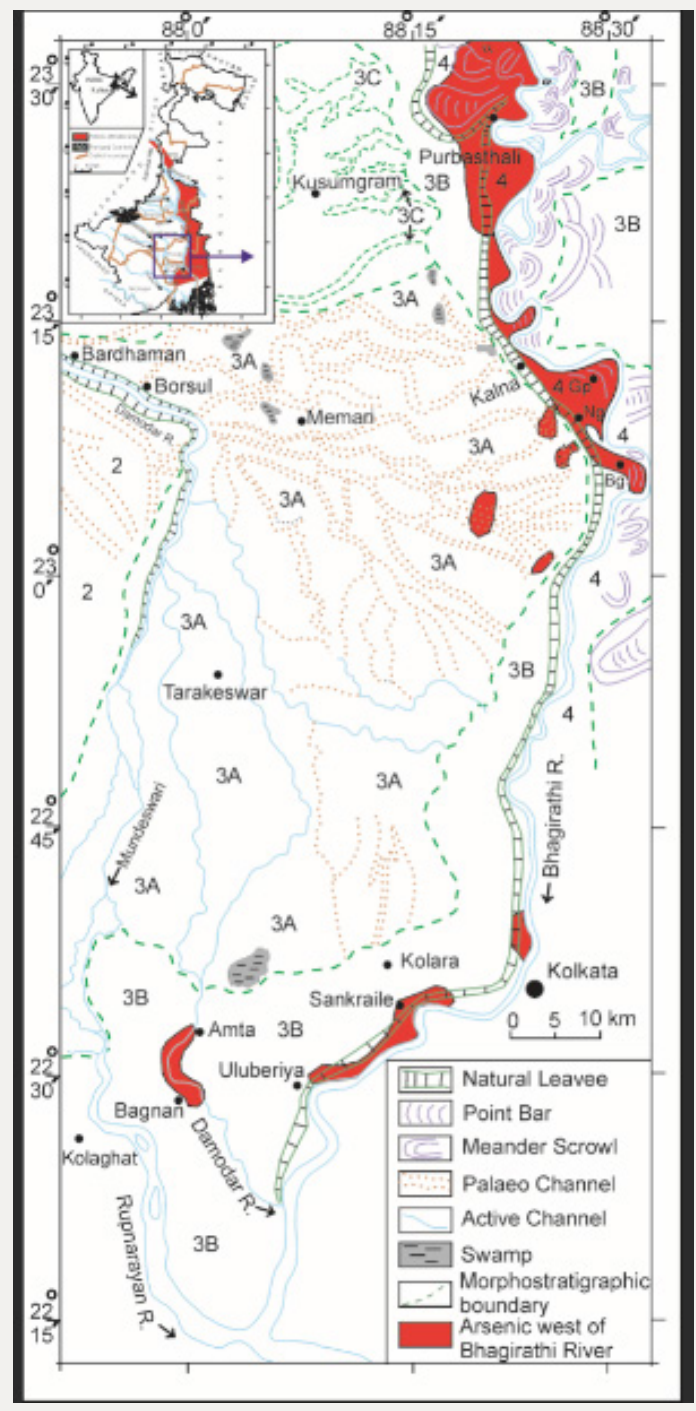

Figure 2: Geomorphologic and Quaternary-morpho-stratigraphic map west of Bhairathi river.

1-Laterite plain (Pleistocene), 2- Older Alluvial Plain (OAP) Pleistocene-Holocene), 3-Younger Delta Plain YDP (Holocene), 3A Damodar fan-delta; 3B-Bhagirathi delta plain; 4-Recent Bhagirathi plain

\section{Source and Release of Arsenic}

No specific sources of arsenic could be identified for the affected alluvial areas e.g., Bhagirathi-Ganga delta, Damodar fan-delta. Roy Chowdhury et al. [9] and Chakraborti et al. [10] postulated that the opaque particles and pyrite in the aquifer sediments were the source of arsenic. Nickson et al. [4] on the other hand, suggested that arsenic is released by reduction process and sourced from sulphide deposits such as the copper belt in Jharkhand (erstwhile Bihar) and Gondwana coal basins of Damodar valley. The potential sources suggested by Nickson et al. [4], are located far south and lower in level from the arsenic affected Ganga tributary system. Acharyya et al. [1] listed sulphide occurrences, some of which are arsenic bearing, from the Himalayan foothills. As the Himalayan range is subjected to high erosion and intense rainfall during the Holocene, these minor occurrences were transported As-bearing products to the Ganga-Brahmaputra basin. Furthermore, Arsenic concentration in biotite-chlorite bearing silt fraction, from the piedmont areas feeding the Ganga and the Brahmaputra Rivers, are also generally found to be higher than normal. Acharyya et al. [1] and Acharyya \& Shah [7] also reported virtual absence of pyrite or any arsenic minerals in the contaminated aquifer.

The Damodar River system located mainly between the Chhotanagpur and Hazaribagh plateaus exclusively belongs to Peninsular Indian. Gondwana coal basins, minor arsenic mineralizations in mica-belt in Hazaribagh plateau and minor sulphide occurrences in Chhotanagpur plateau might have sourced mild arsenic 
contaminations affecting the Damodar fan-delta [7]. Mineralogical studies on sediment cores and tube well sludge from arsenic affected and unaffected surrounding areas in the Bhagirathi - Ganga delta and Damodar fan-delta corroborate that arsenic rich pyrite or any other arsenic minerals are rare or absent. However, rare presence of biogenic pyrite is recorded in reducing environment often in association of degraded plant remains [8]. Biogenic pyrite is noted to grow along clastic grain boundaries and as cement like overgrowth on magnetite. As-bearing nature of biogenic pyrite indicates co-precipitation and sorbing of arsenic in pyrite. These biogenic pyrites therefore have locked arsenic and thus acted as sinks and not sources of arsenic in groundwater.

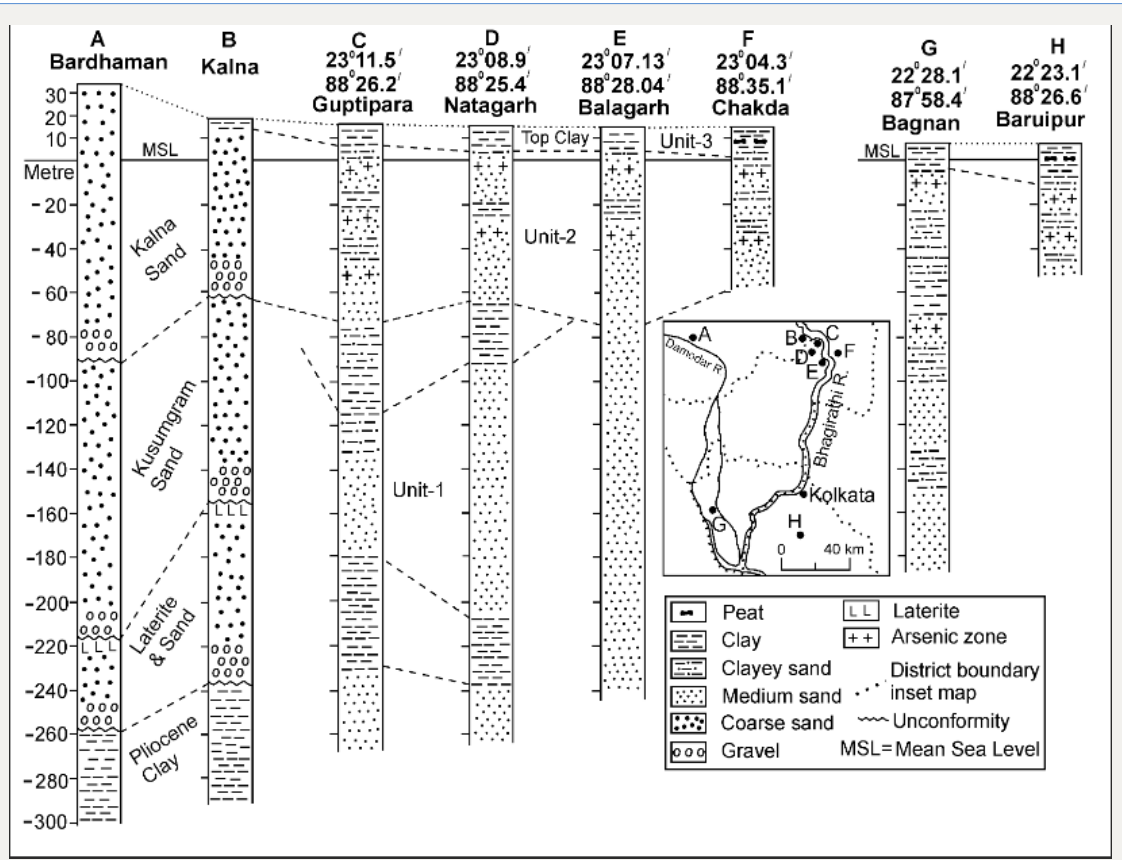

Figure 3: Profile of Holocene sediments across Ganges delta in West Bengal. 1-3 are broad morpho-stratigraphic units.

The oxidation of pyrite and arsenopyrite under oxic condition would release arsenic and produce acid and thus increase concentration of $\mathrm{Fe}$ and $\mathrm{SO}_{4}$ in groundwater. The release of arsenic to groundwater in the Bengal Delta was earlier inferred to be due to oxidation process $[9,10]$. This is unlikely as pyrite or any other As-mineral are absent or rare in alluvial aquifer sediments. Instead, release of arsenic to groundwater in alluvial aquifer is inferred to be caused by reductive dissolution of iron oxyhydroxide mediated by biota $[1,3,4,11]$. Biomediated reductive dissolution of hydrated iron oxide (HFO) that occurs mainly as adsorbed coatings on sediment grains and corresponding oxidation of sedimentary organic matter is regarded as the main mechanism.

Ferrous ion, released by the IRB from sediment coatings of HFO or other Fe-bearing mineral phases possibly reacted with abundantly present bicarbonate in groundwater to precipitate siderite concretions, which grew around sediment grains and/or centers of IRB colony [12]. Biogenic objects a few microns in length and less than a micron width occur inside some of these concretions, which recorded the presence of bacteria [13]. Reduction of HFO is common and intense in affected aquifers in the BhagirathiGanga delta plain as indicated by high maximum concentration of dissolved Fe $(\leq 9-36 \mathrm{mg} / \mathrm{L})$ in contaminated groundwater with maximum arsenic concentration reaching around $1000 \mu \mathrm{g} / \mathrm{L}$. The chemistry of arsenic-affected water in West Bengal and Bangladesh, is based on studies of samples from different depths. An inflatable packer-stradle-pump assembly was used [14] to test chemical and microbiological characteristics of aquifer water from specific depth from an experimental tube well (23 0 04.3': 88 - 35.1') in Chakda area. Sediment and water analysis indicates that ironreducing condition has developed at several levels together with the presence of iron-reducing bacterial activity where reduction of hydrated-ferric oxide was able to mobilize arsenic from sediment to groundwater. Although arsenic is present in the aquifer sediment throughout the depth of the borehole, it did not have any relation to release of arsenic to groundwater. Nitrate and sulfate-reducing conditions were not capable of releasing arsenic.

\section{Dugwell as Low-Cost Source of Arsenic Safe Water}

Dugwell water because of their oxygenated nature is useful source of arsenic safe water, even within arsenic-affected areas. Thus Dugwells are potential source of As-safe water. This is particularly attractive proposition for areas located away from suitable surface water sources. Villagers living in pandemically arsenic contaminated Bengal delta were advised not to use surface water but switch to bacterial free piped water. Even existing dugwells generally found to be ill maintained and bacterially contaminated. Where there is no piped supply of arsenic free drinking water, villagers are to be campaigned to use dugwell. A dugwell could be maintained catering to a small family and kept clean. It is satisfying to note that dugwells with annular screens of 
sand and gravel have proved to be very effective practical solution in some arsenic affected areas of Bengal.

\section{Conclusion}

Arsenic pollution in groundwater is a pandemic environmental problem mainly affecting deltaic areas of Bangladesh and its parts in West Bengal. Upland areas are largely unaffected. Source of arsenic is mainly from the Himalayas, but not as any arsenic bearing mineral but as hydrated iron oxide with adsorbed arsenic. These coat sediment grains and occur in organic matter. During biomediated reductive dissolution, they release arsenic to groundwater continually. Groundwater based irrigation, through shallow tube wells brought in 'Green Revolution' and reduced child mortality and diarrheal cases, but at the same time triggered release of arsenic to groundwater. Arsenic affected aquifers are confined to organic rich early-mid Holocene sediments that were deposited in entrenched channels located between Pleistocene uplands during mid Holocenee sea-level regressive-transgressive cycle.

\section{References}

1. Sebsebe D, Friis I (2009) Natural vegetation of the Flora area. In: Hedberg I, Friis I, Persson (Eds.), Flora of Ethiopia and Eritrea, Uppsala, Sweden, 8: 27-38.

2. Dawit A, Ahadu A (1993) Medicinal plants and enigmatic health practice of North Ethiopia. Berehanina Selam Printing Enterprise, Addis Ababa, Ethiopia.

3. De Candolle A (1882) Origins de plantes cultivees. Paris, France.

4. Vavilov NI (1940) The theory of the origin of cultivated plants after Darwin. Soviet Science 2: 55-75.

5. Vavilov NI (1951) The origin, variation, immunity and breeding of cultivated plants, Chronica Botanica13: 1-366.

6. Vavilov NI (1992) Origin and geography of cultivated plants. Cambridge University Press, Cambridge, UK.

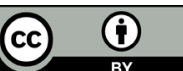

Creative Commons Attribution 4.0 International License

For possible submissions Click Here

\section{Submit Article}

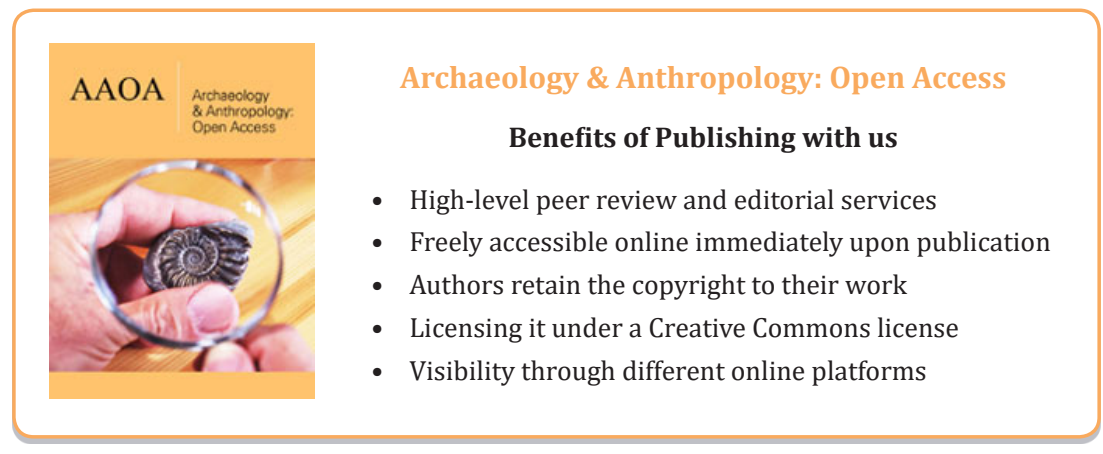

